Syntax Literate : Jurnal Ilmiah Indonesia p-ISSN: 2541-0849

e-ISSN: 2548-1398

Vol. 5, No. 6, Juni 2020

\title{
PENGARUH ASUHAN KEFARMASIAN TERHADAP KUALITAS HIDUP PASIEN DIABETES MELITUS TIPE 2 DI PUSKESMAS KABUPATEN CIREBON
}

\section{Devi Yava Rony, Prih Sarnianto dan Yusi Anggriani}

Magister Farmasi, Universitas Pancasila Jakarta

Email : deviyavarony77@gmail.com,prih1488@gmail.com dan yusi1777@yahoo.com

\section{Abstract}

Pharmacy care in patients with type 2 diabetes mellitus is expected to improve medication adherence so that blood glucose is controlled and optimal quality of life. This study was conducted to determine the effect of pharmaceutical care in improving medication adherence, controlling blood glucose levels and quality of life for type 2 DM patients. This was a prospective study using a comparative quasi-experimental design (control group design with pre-test-post-test). A total of 80 patients consisted of 40 non-Prolanis Talun Puskesmas patients (intervention, given pharmaceutical care) with total sampling and 40 non-Prolanis Karangsari Puskesmas patients (control, without pharmaceutical care) with consecutive sampling. Data were obtained from MMAS-8 (compliance), SF-36 (quality of life) and GDP, GDPP questionnaires from laboratory results. The Wilcoxon Test results showed a significant increase ( $p<0.005)$ before and after pharmaceutical care for levels of compliance, levels of GDP, GDPP and quality of life of patients in the intervention group. Mann Whitnney Test Results showed a significant improvement ( $p$ <0.05), GDPP and quality of life due to pharmaceutical care in patients in the intervention group. Pharmaceutical care can improve compliance, control levels of $G D P, G D P P$ and quality of life for non-Prolanis DM type 2 patients in certain health centers in Cirebon District.

Keywords: Pharmaceutical care, Quality of life and DM patients.

\begin{abstract}
Abstrak
Asuhan kefarmasian pada pasien Diabetes Melitus tipe 2 diharapkan dapat meningkatkan kepatuhan minum obat sehingga glukosa darah terkendali dan kualitas hidup optimal. Penelitian ini dilakukan untuk mengetahui pengaruh asuhan kefarmasian dalam meningkatkan kepatuhan minum obat, pengendalian kadar glukosa darah dan kualitas hidup pasien DM tipe 2. Penelitian bersifat prospektif menggunakan desain kuasi eksperimental komparatif (control group design withpre-test-post-test). Sebanyak 80 pasien terdiri dari 40 pasien non-Prolanis Puskesmas Talun (intervensi, diberi asuhan kefarmasian) dengan total sampling dan 40 pasien non-Prolanis Puskesmas Karangsari (kontrol, tanpa asuhan kefarmasian) dengan consecutive sampling. Data diperoleh dari kuesioner MMAS-8 (kepatuhan), SF-36 (kualitas hidup) dan kadar GDP, GDPP dari hasil laboratorium. Hasil Uji Wilcoxon menunjukkan peningkatan signifikan $(\mathrm{p}<0,005)$ sebelum dan sesudah asuhan kefarmasian terhadap tingkat kepatuhan, kadar GDP, GDPP dan kualitas
\end{abstract}


hidup pasien kelompok intervensi.Hasil Uji Mann Whitnney menunjukkan peningkatan signifikan $(\mathrm{p}<0,05)$ tingkat kepatuhan, kadar GDP, GDPP dan kualitas hidup akibat asuhan kefarmasian pada pasien kelompok intervensi. Asuhan kefarmasian dapat meningkatkan kepatuhan, keterkendalian kadar GDP, GDPP dan kualitas hidup pasien non-Prolanis DM tipe 2 pada puskesmas tertentu di Kabupaten Cirebon.

Kata kunci: Asuhan kefarmasian, Kualitas hidup dan Pasien DM.

\section{Pendahuluan}

Pengaruh era globalisasi di segala bidang, perkembangan teknologi dan industri mengakibatkan perubahan pada perilaku dan gaya hidup masyarakat serta situasi lingkungan, seperti perubahan terhadap pola konsumsi makanan yang serba instan, serta perkembangan dunia teknologi dan komunikasi yang semakin meninggi membuat manusia seakan enggan untuk bergerak dan berolahraga. Perubahan tersebut memberi kontribusi terhadap semakin meningkatnya beberapa penyakit, sebagaimana penyakit jantung, kanker, penyakit saluran pernapasan dan diabetes melitus (Subandi, 2017).

Diabetes melitus (DM) didefenisikan sebagai suatu penyakit atau gangguan metabolisme kronis dengan multi-etiologi yang ditandai dengan tingginya kadar glukosa darah disertai dengan gangguan metabolisme karbohidrat, lipid dan protein sebagai akibat insufiensi fungsi insulin (Organization, 2006). Gaya hidup modern yang semakin luas membuat prevalensi DM meningkat di seluruh dunia, termasuk Indonesia.World Health Organization (WHO) memprediksi penyandang DM di Indonesia akan meningkat dari 8,4 juta pada 2000 menjadi sekitar 21,3 juta pada 2030, atau dua kali lipat lebih dalam waktu 30 tahun. Menurut data Riset Kesehatan Dasar (Riskedas) 2013, prevalensi nasional DM di Indonesia berdasarkan diagnosis dan gejala sekitar $2,1 \%$ dan meningkat sesuai dengan bertambahnya umur, namun mulai umur $\geq 65$ tahun cenderung menurun. Prevalensi DM pada perempuan cenderung lebih tinggi dibandingkan pada laki-laki. Proporsi DM terbesar di Provinsi Nusa Tenggara Timur $(2,1 \%)$ dan Sulawesi Tengah $(2,1 \%)$, sedangkan jumlah terbesar di Provinsi Jawa Barat 225.136 (Kemenkes, 2013).

Asuhan kefarmasian atau pharmaceutical care merupakan komponen dari praktek kefarmasian yang memerlukan interaksi langsung apoteker dengan pasien untuk menyelesaikan masalah terapi pasien dengan obat (Organization, 2006). Asuhan kefarmasian meliputi pengkajian dan pelayanan resep, Pelayanan Informasi Obat (PIO), konseling, visite pasien (khusus puskesmas rawat inap), Monitoring Efek Samping Obat (MESO), Pemantauan Terapi Obat (PTO), Evaluasi Penggunaan Obat (Permenkes, 2016). Asuhan kefarmasian terutama dibutuhkan untuk memastikan efektivitas pelayanan kesehatan bagi pasien penyakit kronis seperti diabetes melitus.

Pengelolaan DM memerlukan penanganan secara mulitidisiplin yang mencakup terapi obat dan terapi non-obat. Kebanyakan pasien dengan DM tidak mendapatkan perawatan optimal, sehingga seringkali kadar glukosa darah tidak terkontrol dengan baik. Masalah ini memberikan kesempatan pada apoteker memberikan kontribusi 
melalui intervensi farmasi berupa asuhan kefarmasian dalam pengendalian glukosa darah pasien DM sehingga tercapai kualitas hidup yang optimal (Depkes, 2005).

Menurut WHO, Kualitas hidup (quality of life, QoL) adalah persepsi individu tentang keberadaannya di kehidupan dalam konteks budaya dan sistem nilai tempat ia tinggal (Organization, 1997). Kualitas hidup terkait kesehatan (HRQoL) adalah konsep multi dimensi yang mencakup domain yang berkaitan dengan fungsi fisik, mental, emosional, dan sosial. Hal ini melampaui ukuran langsung kesehatan populasi, harapan hidup, dan penyebab kematian, dan berfokus pada dampak status kesehatan terhadap kualitas hidup. Konsep HRQoL terkait adalah kesejahteraan, yang menilai aspek positif dari kehidupan seseorang, seperti emosi positif dan kepuasan hidup (Organization, 1997).

HRQoL tidak dapat diukur secara langsung tetapi dengan mengukur indikatorindikatornya menggunakan kuesioner standar seperti SF-36. Kuesioner yang dikembangkan Rand Corporation, Amerika Serikat, ini terlaris memiliki 8 domain kesehatan, yakni kesehatan umum, fungsi fisik, keadaan fisik, keadaan emosional, fungsi social, Nyeri tubuh, vitalitas dan kesehatan mental (Ware Jr \& Sherbourne, 1992).

Berdasarkan penjelasan diatas, maka dilakukan penelitian untuk membuktikan pentingnya asuhan kefarmasian terhadap meningkatnya kualitas hidup pasien DM tipe 2 di Puskesmas Kabupaten Cirebon.

\section{Metode Penelitian}

Penelitian ini menggunakan desain kuasi eksperimental komporatif dengan rancangan Pre-Test - Post-Test grup kontrol yang bersifat prospektif pada pasien DM tipe 2 di Puskesmas Talun sebagai kelompok intervensi dan Puskesmas Karangsari sebagai kelompok kontrol, Kabupaten Cirebon, pada periode April-Juli 2018. Data sekunder diperoleh dari rekam medis, dan data primer melalui wawancara menggunakan kuesioner terstruktur selama 4 bulan. Data yang dikumpulkan meliputi kepatuhan minum obat, kadar glukosa darah (GDP, GDPP) dan kualitas hidup.

Pasien DM tipe 2 non-Prolanis di Puskesmas Talun, ada 40 pasien sehingga digunakan teknik total sampling. Pada Puskesmas Karangsari pengambilan responden pasien non-Prolanis menggunakan teknik consecutive sampling untuk mencapai jumlah yang disesuaikan dengan pasien non-Prolanis $( \pm 5 \%)$ di Puskesmas Talun.

Variabel dalam penelitian ini terdiri dari varibel dependent yaitu kualitas hidup (Quality of Life/QoL) dan independent yaitu asuhan kefarmasian yang meliputi edukasi, monitoring kepatuhan minum obat dan kadar glukosa darah (GDP, GDPP). Variabel pengganggu (confounding factor) dalam penelitian ini, yaitu umur, jenis kelamin, pendidikan, pekerjaan, pendapatan, riwayat DM, lama DM, komorbiditas dan Indeks Massa Tubuh (IMT).

Alat yang digunakan pada penelitian meliputi booklet untuk sarana edukasi, kuesioner MMAS-8 untuk mengukur kepatuhan minum obat, data sekunder diperoleh 
dari rekam medis pasien dan kuesioner SF-36 untuk mengukur kualitas hidup pasien DM tipe 2.

Analisis dan pengolahan data menggunakan program SPSS. Analisa deskriptif digunakan untuk karakteristik pasien DM tipe 2. Uji normalitas menggunakan Uji Kolmogorov Smirnov, Uji statistik parametrik dengan Independent $T$ test dan nonparametrik dengan Uji Mann Withney. Uji statistik untuk pre-test dan post-test digunakan Independent $T$ test dan non-parametrik dengan Uji Wilcoxon.

\section{Hasil dan Pembahasan}

\section{Karakteristik Pasien}

Karakteristik pasien DM tipe 2 sebagaimana disajikan pada tabel 1, diantaranya umur responden. Pada kelompok kontrol rerata umur 54,7 (8,5) dan kelompok intervensi 56,8 $(8,7)$. Karakteristik umur didominasi umur $\geq 60$ tahun $(42,5 \%)$ pada kelompok kontrol dan intervensi. Hasil tersebut memberikan gambaran bahwa karakteristik umur pasien DM type 2 terbanyak pada umur $\geq 60$ tahun . Hal ini disebabkan karena semakin lanjut usia seseorang, produksi insulin oleh pankreas akan semakin berkurang. Pada usia diatas 45 tahun, sel beta pankreas mengalami penurunan baik jumlah maupun fungsinya, seiring dengan berjalannya usia (Holt, 2009). Hal ini sejalan dengan pernyataan bahwa di Indonesia rata-rata pasien DM ada pada usia yang masih tergolong produktif yaitu 45 sampai 64 tahun (Kemenkes, 2013). Menurut Perkumpulan Endokrinologi Indonesia salah satu faktor risiko DM adalah orang yang berumur lebih dari 45 tahun. Resiko DM makin meningkat sesuai dengan perkembangan usia. Semakin tua kecenderungan menderita DM semakin tinggi (Ware Jr \& Sherbourne, 1992).

Jenis kelamin perempuan proporsinya lebih tinggi dibandingkan laki-laki yaitu $85 \%$ kelompok kontrol dan 92,5\% kelompok intervensi. Hasil penelitian ini sejalan dengan yang disajikan oleh Kemenkes pada 2015 bahwa populasi pasien DM yang ada di Indonesia adalah perempuan (225.136) (Kemenkes, 2015). Demikian Juga dengan hasil penelitian yang menyatakan bahwa pada usia 45 tahun keatas sebagian wanita sudah mulai mengalami menopause, dimana hormon esterogen dan progesteron pun berkurang. Hormon esterogen berfungsi untuk menjaga keseimbangan kadar glukosa darah dan progesteron berfungsi untuk menormalkan kadar glukosa darah setiap saat bila asupan glukosa kedalam tubuh berlebih. Hal tersebut yang membuat wanita lebih cenderung mengalami DM dibandingkan laki-laki (Wicaksono, 2011).

Karakteristik pendidikan pada kelompok kontrol dan intervensi menunjukkan pendidikan dasar lebih tinggi proporsinya dibandingkan pendidikan menengah/atas yaitu kelompok kontrol 72,5\% dan kelompok intervensi 67,5\%. Hasil penelitian ini sejalan dengan data dari Kemenkes 2015, pasien DM terbanyak di Indonesia adalah level pendidikan Sekolah Dasar (Kemenkes, 2015). Semakin tinggi tingkat pendidikan seseorang berbanding lurus dengan semakin tingginya kemampuan orang tersebut untuk mengatur pola hidupnya agar tetap sehat. Tingkat pengetahuan 
pada setiap individu salah satunya dapat dipengaruhi oleh status pendidikan, dimana kemampuan dalam mendapatkan informasi tentang penyakit-penyakit secara umum lebih banyak (Mongisidi, 2014).

Karakteristik pekerjaan menunjukkan kelompok kontrol dan intervensi tidak bekerja lebih tinggi proporsinya dibandingkan bekerja yaitu kelompok kontrol 70\% dan kelompok intervensi 67,5\%. Hasil ini sejalan dengan pernyataan yang dikeluarkan Kemenkes pada 2015 bahwa DM dengan pekerjaan ibu rumah tangga menempati posisi nomor dua tertinggi yaitu 7,4\% setelah pekerjaan lain-lain 9,3\% (Kemenkes, 2015) Aktifitas fisik akan membuat kadar insulin lebih meningkat. Tanpa adanya kombinasi dengan olahraga yang cukup maka kecenderungan pekerjaan ibu rumah tangga lebih banyak dalam populasi DM di masyarakat (Wicaksono, 2011).

Karakteristik pendapatan didominasi pendapatan $\leq 1.000 .000$. Kelompok kontrol $75 \%$ dan kelompok intervensi $80 \%$. Karakteristik pendapatan dalam penelitian ini pada kelompok kontrol dan intervensi hampir sama. Hal ini karena responden lebih banyak tidak bekerja dibandingkan bekerja. Hasil penelitian ini sejalan dengan yang dilakukan di Kanada bahwa masyarakat yang berpendapatan rendah berisiko $77 \%$ lebih tinggi terkena penyakit DM Tipe 2 dibanding dengan orang yang berpendapatan tinggi (Dinca-Panaitescu et al., 2012) Senada juga dengan penelitian bahwa seseorang yang mempunyai tingkat sosial ekonomi yang rendah diantaranya pendidikan yang rendah, pendapatan yang rendah, dan tidak memiliki suatu pekerjaan yang tetap memiliki prevalensi yang lebih tinggi untuk menderita DM Tipe 2 (Funakoshi et al., 2017). Penelitian yang dilakukan di Adelaide Australia mendapatkan hasil bahwa pendapatan rumah tangga (belum dipotong pajak) di bawah dari $\$ 20.000$ per tahun memiliki risiko untuk terkena Diabetes Melitus tipe 2 (Grant et al., 2009). Hal tersebut dikarenakan perubahan sosial ekonomi dan selera makan akan mengakibatkan perubahan pola makan masyarakat yang cenderung menjauhkan konsep makanan seimbang, sehingga berdampak negatif terhadap kesehatan dan gizi (Mongisidi, 2014).

Pada penelitian ini, proporsi tidak ada riwayat DM lebih tinggi dibandingkan ada riwayat DM. Kelompok kontrol 80\%. Kelompok intervensi 77,5\%. Meskipun faktor keturunan memiliki pengaruh dalam menentukan seseorang berisiko terkena DM atau tidak, gaya hidup juga memiliki peran besar terhadap risiko terjadinya DM Tipe 2 (Wicaksono, 2011). Hasil ini sejalan dengan hasil penelitian bahwa riwayat DM bukanlah satu-satunya faktor yang berhubungan dengan kejadian DM Tipe 2. Diketahui bahwa ada sekitar $41 \%$ responden yang telah didiagnosis menderita DM Tipe 2 namun tidak memiliki riwayat DM. Penelitian yang dilakukan di Poliklinik Penyakit Dalam Rumah Sakit Dr. Kariadi Semarang menunjukkan bahwa salah satu faktor yang berhubungan dengan kejadian DM Tipe 2 yaitu aktivitas fisik olahraga. Oleh karena itu, pencegahan diabetes bagi yang berisiko dapat dilakukan dengan membiasakan hidup sehat dan berolahraga secara teratur (Wicaksono, 2011). 
Karakteristik lama menderita DM dalam penelitian ini dibagi 4 yaitu $<2$ tahun, 2 - 3 tahun, 3-4 tahun, >4 tahun. Secara umum lama DM lebih banyak 2-3 tahun. Kelompok kontrol dengan lama DM paling banyak 2-3 tahun $30 \%$, dan kelompok intervensi $27,5 \%$. Pasien yang menderita DM tipe 2 dalam rentang waktu kurang 5 tahun lebih banyak dari pada pasien yang sudah terkena lebih 5 tahun. Semakin lama seseorang menderita DM maka semakin besar peluang terjadinya komplikasi, terutama pada penderita DM yang memiliki glukosa darahnya tidak terkontrol dengan baik. Durasi diabetes melitus yang semakin lama juga dapat menurunkan sekresi insulin dan meningkatkan risiko penyakit salah satunya penyakit jantung koroner. Risiko meningkat 1,38 kali lebih tinggi untuk setiap 10 tahun dalam kenaikan durasi DM dan risiko kematian akibat penyakit jantung koroner menjadi 1,86 kali lebih tinggi. Tujuh dari sepuluh pasien dengan DM di Indonesia akan terjadi komplikasi yang pada akhirnya akan mengurangi kualitas hidup dan menyebabkan kematian (Wicaksono, 2011).

Karakteristik komorbiditas proporsi lebih tinggi pada tidak ada komorbiditas. Kelompok kontrol 75\% dan kelompok intervensi 65\%. Komorbiditas atau penyakit penyerta pasien DM tipe 2 pada penelitian ini adalah hipertensi. Proporsi komorbid lebih tinggi pada tidak ada komorbiditas. Kelompok kontrol 75\% dan kelompok intervensi $65 \%$. Penyakit penyerta yang paling banyak diderita pasien adalah hipertensi $(25,6 \%)$ dan pada umumnya pasien DM juga menderita hipertensi. Kejadian hipertensi pada pasien lanjut usia penderita DM akan meningkat, prevalensi $40 \%$ pada usia 45 tahun meningkat menjadi $60 \%$ pada usia 75 tahun (Handaka ES, Pinasti U., 2015).

Karakteristik IMT dibagi 3 yaitu BB normal (IMT : 8,5-22,9), BB lebih (IMT : 23-24,9) dan obesitas I (IMT : 25,0-29,9). Secara umum proporsi IMT responden paling tinggi adalah BB normal. Kelompok kontrol 45\% dan kelompok intervensi BB normal dan BB lebih 42,5\%. Indeks Massa Tubuh (IMT) adalah perbandingan berat badan dalam kilogram dengan tinggi badan dalam meter kuadrat. Metoda ini digunakan untuk menentukan berat badan yang sehat berdasarkan berat dan tinggi badan. IMT ini untuk menujukkan kategori berat badan seseorang apakah sudah proporsional atau belum. Karakteristik IMT dalam penelitian ini secara umum proporsi IMT responden paling tinggi adalah BB normal. Hasil ini sesuai dengan penelitian yang dilakukan bahwa terdapat hubungan antara IMT dengan kadar gula darah penderita DM Tipe 2. Semakin tinggi nilai IMT semakin tinggi pula kadar gula darahnya (Ain F., 2012). 
Tabel 1

Karakteristik Umum Pasien Non-Prolanis DM Tipe

\begin{tabular}{|c|c|c|c|c|}
\hline \multirow{2}{*}{ Variabel } & \multicolumn{2}{|c|}{ Kontrol } & \multicolumn{2}{|c|}{ Intervensi } \\
\hline & $(\mathrm{n}=40)$ & Proporsi (\%) & $(\mathrm{n}=40)$ & Proporsi $(\%)$ \\
\hline \multicolumn{5}{|l|}{ Umur } \\
\hline Rentang & $38-76$ & - & $39-73$ & - \\
\hline Median & 53,5 & - & 56,5 & - \\
\hline Rerata (SD) & $54,7(8,3)$ & - & $56,8(8,7)$ & - \\
\hline a. $<40$ tahun & 3 & 7,5 & 4 & 10 \\
\hline b. $40-49$ tahun & 7 & 17,5 & 6 & 15 \\
\hline c. 50-59 tahun & 13 & 32,5 & 13 & 32,5 \\
\hline d. $\geq 60$ tahun & 17 & 42,5 & 17 & 42,5 \\
\hline \multicolumn{5}{|l|}{ Jenis Kelamin } \\
\hline a. Laki-laki & 6 & 15 & 3 & 7,5 \\
\hline b. Perempuan & 34 & 85 & 37 & 92,5 \\
\hline \multicolumn{5}{|l|}{ Pendidikan } \\
\hline a. Dasar & 29 & 72,5 & 27 & 67,5 \\
\hline b Menengah/Atas & 11 & 27,5 & 13 & 32,5 \\
\hline \multicolumn{5}{|l|}{ Pekerjaan } \\
\hline a. Tidak bekerja & 28 & 70 & 27 & 67,5 \\
\hline b. Bekerja & 12 & 30 & 13 & 32,5 \\
\hline \multicolumn{5}{|l|}{ Pendapatan } \\
\hline a. $\leq 1.000 .000$ & 30 & 75 & 32 & 80 \\
\hline b. > 1.000 .000 & 10 & 25 & 8 & 20 \\
\hline \multicolumn{5}{|l|}{ Riwayat DM } \\
\hline a. Ada & 8 & 20 & 9 & 22,5 \\
\hline b. Tidak & 32 & 80 & 31 & 77,5 \\
\hline \multicolumn{5}{|l|}{ Lama DM } \\
\hline a. $<2$ tahun & 10 & 25 & 9 & 22,5 \\
\hline b. $2-3$ tahun & 12 & 30 & 11 & 27,5 \\
\hline c. 3 - 4 tahun & 10 & 25 & 9 & 22,5 \\
\hline d. $>4$ tahun & 8 & 20 & 11 & 27,5 \\
\hline \multicolumn{5}{|l|}{ Komorbiditas } \\
\hline a. Ada & 10 & 25 & 14 & 35 \\
\hline b. Tidak ada & 30 & 75 & 26 & 65 \\
\hline \multicolumn{5}{|l|}{ IMT } \\
\hline a. BB normal & 18 & 45 & 17 & 42,5 \\
\hline b. BB lebih & 15 & 37,5 & 17 & 42,5 \\
\hline c. Obesitas I & 7 & 17,5 & 6 & 15 \\
\hline
\end{tabular}

\section{Hasil Analisis Bivariat}

Pengaruh asuhan kefarmasian pre-test dan post-test terhadap kepatuhan minum obat, kadar GDP, GDPP dan kualitas hidup pasien DM Tipe 2 dengan Uji Wilcoxon dan perbedaan kelompok kontrol dan intervensi dengan Uji Mann Whitney disajikan pada tabel 2, tabel 3, tabel 4 dan tabel 5. 
Pengaruh Asuhan Kefarmasian Terhadap Kualitas Hidup Pasien Diabetes Melitus Tipe 2

Tabel 2

Hasil Pre-test dan Post-test Tingkat Kepatuhan Minum Obat Pasien DM Type 2.

\begin{tabular}{|c|c|c|c|c|c|}
\hline \multirow{3}{*}{$\begin{array}{l}\text { Tingkat } \\
\text { Kepatuhan }\end{array}$} & \multicolumn{4}{|c|}{ Pasien DM } & \multirow[t]{2}{*}{ Sig**) } \\
\hline & \multicolumn{2}{|c|}{ Kontrol $(\mathrm{N}=40)$} & \multicolumn{2}{|c|}{ Intervensi $(\mathrm{N}=40)$} & \\
\hline & Pre-test & Post-test & Pre-test & Post-test & \\
\hline a. Tinggi & 0 & 0 & 0 & 22 & \\
\hline b. Sedang & 0 & 0 & 1 & 17 & \\
\hline c. Rendah & 40 & 40 & 39 & 1 & \\
\hline Rata-rata & 2,31 & 2,34 & 2,61 & 7,23 & \\
\hline$\Delta$ Postest-Pretest & \multicolumn{2}{|c|}{0,03} & \multicolumn{2}{|c|}{4,62} & $\mathbf{0 , 0 0}$ \\
\hline Sig*) & \multicolumn{2}{|c|}{1,00} & \multicolumn{2}{|c|}{$\mathbf{0 , 0 0}$} & \\
\hline
\end{tabular}

Tabel 3

Nilai GDP Pasien Kelompok Kontrol dan Intervensi

\begin{tabular}{lccccc}
\hline \multirow{2}{*}{ GDP } & \multicolumn{4}{c}{ Pasien } & Sig**) \\
\cline { 2 - 6 } & \multicolumn{2}{c}{ Kontrol (N=40) } & Intervensi (N =40) & \\
\cline { 2 - 6 } & Pre-test & Post-test & Pre-test & Post-test & \\
\hline a.Terkendali baik & 0 & 0 & 0 & 10 & \\
\hline b. Terkendali sedang & 3 & 2 & 1 & 22 & \\
\hline c. Terkendali buruk & 37 & 38 & 39 & 8 & \\
\hline Rata-rata & 181,10 & 180,48 & 157,52 & 115,30 & \\
\hline$\Delta$ Postest - Pretest & 0,62 & \multicolumn{5}{c}{42,22} & \\
\hline \multicolumn{1}{c}{ Sig*) } & $\mathbf{0 , 6 2 7}$ & $\mathbf{0 , 0 0}$ & & 0,00 \\
\hline
\end{tabular}

Keterangan : *) Hasil Uji Wilcoxon, **) Hasil Uji Mann-Whitney

Tabel 4

Nilai GDPP pasien pada kelompok kontrol dan intervensi

\begin{tabular}{|c|c|c|c|c|c|}
\hline \multirow{3}{*}{ GDPP } & \multicolumn{4}{|c|}{ Pasien } & Sig**) \\
\hline & \multicolumn{2}{|c|}{ Kontrol $(\mathrm{N}=40)$} & \multicolumn{2}{|c|}{ Intervensi $(\mathrm{N}=40)$} & \\
\hline & Pre-test & Post-test & Pre-test & Post-test & \\
\hline \multirow{3}{*}{$\begin{array}{l}\text { a. Terkendali baik } \\
\text { b. Terkendali } \\
\text { sedang } \\
\text { c. Terkendali } \\
\text { buruk }\end{array}$} & 4 & 4 & 0 & 11 & \\
\hline & 4 & 6 & 1 & 7 & \\
\hline & 32 & 30 & 39 & 22 & \\
\hline Rata-rata & 211,4 & 199,7 & 224,85 & 175,55 & \\
\hline$\Delta$ Postest - Pretest & \multicolumn{2}{|c|}{11,7} & \multicolumn{2}{|c|}{49,30} & $\mathbf{0 , 0 0}$ \\
\hline Sig*) & \multicolumn{2}{|c|}{$\mathbf{0 , 0 0}$} & \multicolumn{2}{|c|}{$\mathbf{0 , 0 0}$} & \\
\hline
\end{tabular}

Keterangan : *) Hasil Uji Wilcoxon, **) Hasil Uji Mann-Whitney 
Nilai tingkat kualitas hidup pada pasien DM Type 2

\begin{tabular}{|c|c|c|c|c|c|}
\hline \multirow{3}{*}{$\begin{array}{c}\text { Tingkat } \\
\text { Kualitas Hidup }\end{array}$} & \multicolumn{4}{|c|}{ Non-Prolanis } & \multirow[t]{3}{*}{ Sig**) } \\
\hline & \multicolumn{2}{|c|}{ Kontrol $(\mathrm{N}=40)$} & \multicolumn{2}{|c|}{ Intervensi $(\mathrm{N}=40)$} & \\
\hline & Pre-test & Post-test & Pre-test & Post-test & \\
\hline a. Baik sekali & 0 & 0 & 0 & 9 & \\
\hline b. Baik & 3 & 7 & 16 & 31 & \\
\hline c. Cukup & 36 & 33 & 24 & 0 & \\
\hline d. Kurang & 1 & 0 & 0 & 0 & \\
\hline Rata-rata & 39,95 & 42,45 & 47,30 & 71,33 & \\
\hline $\begin{array}{l}\Delta \text { Postest - } \\
\text { Pretest }\end{array}$ & \multicolumn{2}{|c|}{2,50} & \multicolumn{2}{|c|}{24,03} & \\
\hline Sig*) & \multicolumn{2}{|c|}{0,255} & \multicolumn{2}{|c|}{$\mathbf{0 , 0 0}$} & $\mathbf{0 , 0 0}$ \\
\hline
\end{tabular}

Keterangan : *) Hasil Uji Wilcoxon, $\left.{ }^{* *}\right)$ Hasil Uji Mann-Whitney

\section{a. Pengaruh Asuhan Kefarmasian Terhadap Kepatuhan Minum Obat}

Perbedaan kepatuhan minum obat pasien kelompok kontrol pre-test dan post-test dengan Uji Wilcoxon diperoleh nilai p-value $(1,00)>0,05$, sedangkan pada pasien kelompok intervensi pre-test dan post-test diperoleh nilai $\mathrm{p}$-value $(0,00)<0,05$. Perbedaan tingkat kepatuhan antara pasien kelompok kontrol dan intervensi diuji dengan Uji Mann Whitney diperoleh nilai p-value $(0,00)<0,05$. Berdasar hasil penelitian dapat disimpulkan bahwa, pada pasien kelompok kontrol tidak ada perubahan tingkat kepatuhan pada saat sebelum (pre-test) dan sesudah (post-test) penelitian yaitu pada tingkat kepatuhan rendah, sedang dan tinggi. Hal ini disebabkan karena tidak adanya asuhan kefarmasian yang diberikan oleh peneliti.

Pasien kelompok intervensi terdapat perubahan sebelum (pre-test) dan sesudah diberikan asuhan kefarmasian (post-test). Tingkat kepatuhan rendah berkurang sedangkan tingkat kepatuhan sedang dan tinggi jadi bertambah. Hal ini menunjukkan ada perbedaan signifikan sebelum (pre-test) dan sesudah (posttest) diberikan asuhan kefarmasian. Jadi asuhan kefarmasian berpengaruh terhadap peningkatan kepatuhan minum obat pasien pre-test dan post-test kelompok intervensi. Perbedaan pengaruh asuhan kefarmasian terhadap kepatuhan minum obat pasien DM tipe 2 antara kelompok kontrol dengan intervensi terdapat perbedaan yang signifikan. Hal ini menunjukkan asuhan kefarmasian berpengaruh terhadap kepatuhan minum obat kelompok intervensi.

Hasil ini sesuai dengan penelitian di Puskesmas Srandakan Bantul bahwa terdapat perbedaan signifikan antara kepatuhan pasien dalam penggunaan obat sebelum dan setelah pelaksanaan home care pada pasien DM tipe 2 dengan komplikasi hipertensi (Setiawan, 2019). Demikian pula sejalan dengan penelitian di Puskesmas Kramat Jati Jakarta Timur yang menunjukkan adanya perbedaan yang bermakna sebelum dan sesudah intervensi farmasi pada kepatuhan minum obat pasien DM tipe 2 .

Sejalan pula dengan hasil penelitian di Puskesmas Bambanglipuro dan Puskesmas Pundong bahwa terdapat pengaruh pemberian konseling farmasi 
terhadap tingkat kepatuhan penggunaan obat serta hasil terapi pasien DM tipe 2 di puskesmas dan terdapat hubungan antara tingkat kepatuhan dan hasil terapi (Husna, Sari, \& Halim, 2017). Hasil penelitian di Rumah Sakit Mayapada Tanggerang menyatakan bahwa pemberian booklet dapat meningkatkan pengetahuan dan kepatuhan minum obat pada pasien DM Tipe 2 (Husna et al., 2017). Pemberian booklet sebagai alat edukasi pada pasien DM tipe 2 sangat efektif dapat meningkatkan pengetahuan dan kepatuhan pasien menjalankan pengobatan. Diperkuat pula dengan intevensi farmasis dalam bentuk home pharmacy care. Konseling dalam home pharmacycare dapat meningkatkan kepatuhan pasien diabetes melitus (Husna et al., 2017).

\section{b. Pengaruh Asuhan Kefarmasian terhadap kadar GDP}

Hasil Uji Wilcoxon perbedaan kadar GDP pasien kelompok kontrol pretest dan post-test diperoleh nilai p-value $(0,627)>0,05$, sedangkan pada pasien kelompok intervensi pre-test dan post-test diperoleh nilai p-value $(0,00)<0,05$. Perbedaan kadar GDP antara pasien kelompok kontrol dan intervensi diuji dengan Uji Mann Whitney diperoleh nilai p-value $(0,00)<0,05$. Hasil penelitian terhadap kadar GDP pasien DM type 2 kelompok kontrol sebelum (pre-test) ataupun sesudah (post-test) penelitian tidak ada perubahan yang lebih baik. Hal menunjukkan tidak ada perbedaan yang signifikan antara sebelum tes (pre-test) dan sesudah tes (post-test). Pada pasien kelompok intervensi terdapat perubahan yang lebih baik sebelum (pre-test) dan sesudah diberikan asuhan kefarmasian (post-test). Pasien dengan nilai GDP terkendali buruk menjadi berkurang dan pasien dengan nilai GDP terkendali sedang dan tinggi menjadi bertambah. Hal ini menunjukkan adanya perbedaan yang signifikan lebih baik antara sebelum (pre-test) dan sesudah asuhan kefarmasian (post-test). Adanya perbedaan yang signifikan kadar GDP pasien kelompok kontrol dengan intervensi menunjukkan bahwa asuhan kefarmasian dapat meningkatkan keterkendalian kadar GDP pasien kelompok intervensi. Hasil penelitian ini sejalan dengan penelitian di Puskesmas Pundong Kabupaten Bantul yang menyatakan bahwa terdapat pengaruh konseling farmasi terhadap tingkat kepatuhan minum obat dan hasil terapi pasien DM tipe 2 di puskesmas (Husna N. dkk, 2017). Penelitian yang dilakukan di Puskesmas Kramat Jati Jakarta juga menyebutkan ada perbedaan yang bermakna sebelum dan sesudah intervensi farmasi terhadap pengetahuan, kepatuhan dan kadar GDP dan GDPP (Voni N., 2015).

\section{c. Pengaruh Asuhan Kefarmasian terhadap kadar GDPP}

Uji Wilcoxon yang digunakan untuk mengetahui hubungan kadar GDPP kelompok kontrol pre-test dan post-test diperoleh nilai p-value $(0,00)<0,05$, dan pada pasien kelompok intervensi pre-test dan post-test diperoleh nilai $\mathrm{p}$-value $(0,00)<0,05$. Untuk mengetahui perbedaan kadar GDPP antara pasien kelompok kontrol dan intervensi diuji dengan Uji Mann Whitney diperoleh nilai p-value $(0,00)<0,05$. Berdasarkan data hasil GDPP pasien kelompok kontrol dan intervensi menunjukkan pasien kelompok kontrol sebelum (pre-test) 
ataupun sesudah (post-test) terdapat peningkatan nilai GDPP kategori terkendali sedang. Hal ini menunjukkan peningkatan signifikan pada keterkendalian nilai GDPP antara sebelum (pre-test) dan sesudah (post-test). Pasien kelompok intervensi ada peningkatan keterkendalian nilai GDPP sebelum (pre-test) dan sesudah diberikan asuhan kefarmasian (post-test). Pasien dengan nilai GDPP terkendali buruk menjadi berkurang dan pasien dengan nilai GDPP terkendali sedang dan tinggi menjadi bertambah. Terdapat peningkatan yang signifikan pada keterkendalian nilai GDPP antara sebelum (pre-test) dan sesudah (posttest). Hal ini menunjukkan ada pengaruh asuhan kefarmasian terhadap keterkendalian nilai GDPP pada kelompok kontrol dan intervensi sebelum (pretest) dan sesudah (post-test). Perbedaan GDPP kelompok kontrol dengan kelompok intervensi terdapat perbedaan yang signifikan Hal ini menunjukkan asuhan kefarmasian berpengaruh pada peningkatan keterkendalian nilai GDPP pada pasien kelompok intervensi.

\section{d. Pengaruh Asuhan Kefarmasian terhadap Kualitas Hidup}

Selanjutnya diperoleh hasil Uji Wilcoxon hubungan antara kualitas hidup pasien kelompok kontrol pre-test dan post-test dengan nilai p-value $(0,255)>$ 0,05, sedangkan pada pasien kelompok intervensi pre-test dan post-test diperolehnilai p-value $(0,00)<0,05$.Perbedaan kualitas hidup antara pasien kelompok kontrol dan intervensi diuji dengan Uji Mann Whitney diperoleh nilai p-value $(0,00)<0,05$. Pasien kelompok kontrol sebelum (pre-test) dan setelah (post-test) tidak ada perubahan yang berarti pada tingkat kualitas hidup. Hal ini menunjukkan tidak ada perbedaan yang signifikan sebelum (pre-test) dan sesudah (post-test). Pada pasien kelompok intervensi menunjukkan peningkatan tingkat kualitas hidup sebelum (pre-test) dan sesudah asuhan kefarmasian (posttest). Peningkatan kualitas hidup dari cukup menjadi tingkat kualitas hidup baik dan baik sekali. Hal ini menunjukkan terdapat perbedaan kualitas hidup yang signifikan sebelum (pre-test) dan sesudah (post-test) kelompok intervensi. Perbedaan kualitas hidup antara pasien kelompok kontrol dan kelompok intervensi, terdapat pengaruh signifikan asuhan kefarmasian dalam meningkatkan kualitas hidup pasien kelompok intervensi. Hasil penelitian ini sejalan dengan hasil penelitian di Puskesmas Gedong Tengen bahwa konseling farmasi yang dilakukan oleh farmasis menunjukkan hasil yang signifikan dalam meningkatkan kualitas hidup pasien diabetes melitus tipe 2 (Septiar \& Utami, 2015). Sesuai pula dengan hasil penelitian di Turki yang menyimpulkan bahwa apoteker merupakan komponen kunci dalam pelayanan yang terintegrasi bagi pasien DM. Hasil yang baik dari penelitian ini merupakan motivasi bagi apoteker komunitas untuk melakukan pharmaceutical care bagi penderita diabetes (Turnacilar, Sancar, Apikoglu-Rabus, Hursitoglu, \& Izzettin, 2009).

\section{Kesimpulan}


Asuhan kefarmasian berpengaruh signifikan terhadap peningkatan kepatuhan minum obat, keterkendalian glukosa darah (GDP, GDPP) dan kualitas hidup sebelum (pre-test) dan sesudah (post-test) pada kelompok intervensi. Asuhan kefarmasian berpengaruh signifikan terhadap peningkatan kepatuhan minum obat, keterkendalian kadar glukosa darah (GDP, GDPP) dan kualitas hidup antara pasien kelompok intervensi. Asuhan kefarmasian yang dilakukan peneliti kepada kelompok intervensi mencakup monitoring kepatuhan minum obat dan kadar GDP, GDPP.

\section{BIBLIOGRAFI}


Devi Yava Rony, Prih Sarnianto dan Yusi Anggriani

Depkes, R. I. (2005). Pencegahan dan pemberantasan demam berdarah dengue di Indonesia. Jakarta: Depkes RI.

Dinca-Panaitescu, Mihaela, Dinca-Panaitescu, Serban, Raphael, Dennis, Bryant, Toba, Pilkington, Beryl, \& Daiski, Isolde. (2012). The dynamics of the relationship between diabetes incidence and low income: Longitudinal results from Canada's National Population Health Survey. Maturitas, 72(3), 229-235.

Funakoshi, Mitsuhiko, Azami, Yasushi, Matsumoto, Hisashi, Ikota, Akemi, Ito, Koichi, Okimoto, Hisashi, Shimizu, Nobuaki, Tsujimura, Fumihiro, Fukuda, Hiroshi, \& Miyagi, Chozi. (2017). Socioeconomic status and type 2 diabetes complications among young adult patients in Japan. PloS One, 12(4).

Grant, Janet F., Hicks, Neville, Taylor, Anne W., Chittleborough, Catherine R., Phillips, Patrick J., \& Team, North West Adelaide Health Study. (2009). Gender-specific epidemiology of diabetes: a representative cross-sectional study. International Journal for Equity in Health, 8(1), 6.

Holt, Paula. (2009). Diabetes in hospital: a practical approach for healthcare professionals. John Wiley \& Sons.

Husna, Nurul, Sari, Sri Adelila, \& Halim, Abdul. (2017). Pengembangan Media Puzzle Materi Pencemaran Lingkungan di SMP Negeri 4 Banda Aceh. Jurnal Pendidikan Sains Indonesia (Indonesian Journal of Science Education), 5(1), 66-71.

Kemenkes, R. I. (2013). Riset kesehatan dasar (Riskesdas) 2013. Kemenkes RI. Jakarta.

Kemenkes, R. I. (2015). Profil kesehatan Indonesia tahun 2014. Jakarta: Kemenkes RI.

Mongisidi, Gabby. (2014). Hubungan Antara Status Sosio-Ekonomi dengan Kejadian Diabetes Melitus Tipe 2 Di Poliklinik Interna Blu Rsup Prof. Dr. RD Kandou Manado. Jurnal Ilmiah (Online)(Http://Fkm. Unsrat. Ac. Id/WpContent/Uploads/2015/02/Januari-Gabby-Mongisidi. Pdf, Diakses Pada Tanggal 29 Januari 2018).

Organization, World Health. (1997). Measuring quality of life: The World Health Organization quality of life instruments (the WHOQOL-100 and the WHOQOLBREF). WHOQOL-Measuring Quality of Life.

Organization, World Health. (2006). Definition and diagnosis of diabetes mellitus and intermediate hyperglycaemia: report of a WHO/IDF consultation.

Permenkes, R. I. (2016). No. 6 Tahun 2016 tentang Formularium Obat Herbal Asli Indonesia. Jakarta: Biro Hukum Dan Organisasi Kementrian Kesehatan RI, 6225.

Septiar, Handaka Ekaningputra, \& Utami, Pinasti. (2015). Pengaruh Konseling 
Farmasis Terhadap Kualitas Hidup Dan Kadar Gula Darah Pada Pasien Diabetes Mellitus Tipe 2 Di Puskesmas Gedong Tengen Periode Maret-Mei 2014. Jurnal Farmasi Sains Dan Praktis, 1(1), 29-34.

Setiawan, Adib Rifqi. (2019). Efektivitas pembelajaran biologi berorientasi literasi saintifik. Thabiea: Journal of Natural Science Teaching, 2(2), 83-94.

Subandi, Endang. (2017). Pengaruh Senam Diabetes Perhadap Penurunan Kadar Gula Darah Pada Pasien Diabetes Mellitus Di Upt Puskesmas Mundu Kabupaten Cirebon Tahun 2017. Syntax Literate; Jurnal Ilmiah Indonesia, 2(7), 53-68.

Turnacilar, Mertkan, Sancar, Mesut, Apikoglu-Rabus, Sule, Hursitoglu, Mehmet, \& Izzettin, Fikret Vehbi. (2009). Improvement of diabetes indices of care by a short pharmaceutical care program. Pharmacy World \& Science, 31(6), 689.

Ware Jr, John E., \& Sherbourne, Cathy Donald. (1992). The MOS 36-item short-form health survey (SF-36): I. Conceptual framework and item selection. Medical Care, 473-483.

Wicaksono, Radio Putro. (2011). Faktor-Faktor Yang Berhubungan Dengan Kejadian Diabetes Melitus Tipe 2 (Studi Kasus di Poliklinik Penyakit Dalam Rumah Sakit Dr. Kariadi. Faculty of Medicine. 